\title{
SYMPOSIUM
}

\section{Employment-Based Health Insurance and Universal Coverage: Four Things People Know that Aren't So}

\author{
David A. Hyman *
}

It isn't what we don't know that gives us trouble, it's what we know that ain't so.'

In 2001, I published an article in this journal titled "Two Cheers For Employment-Based Health Insurance."2 That article opened with the following sentence: "Employment-based health insurance is the Rodney Dangerfield of health policy: it gets no respect from anyone." 3 The article then cataloged criticisms of employment-based coverage (EBC) from across the political spectrum, offered various reasons why EBC deserves "two cheers," and proposed tax reform, Employee Retirement Income Security Act (ERISA) reform, and greater use of purchasing pools to address shortcomings in the EBC market. ${ }^{4}$

EBC may not get much respect, but it does have considerable staying power. Consider four recent developments (and non-developments). First, in the 2008 Democratic presidential primaries, only Representative Dennis Kucinich proposed outright replacement of EBC with a one-payer system - and he was out of the race on January 24, 2008, after receiving no delegates in Iowa, $1.35 \%$ of the vote in New Hampshire (fifth place), and 3.65\% in Michigan (third place, but second place went to "uncommitted," who got $40 \%$ of the vote). ${ }^{5}$ Second, the

\footnotetext{
* Richard and Marie Corman Professor of Law and Professor of Medicine, University of Illinois. Tel. 217-333-0061, email: dhyman(aillinois.edu. I appreciate helpful comments from Professors Bill Sage and Gregg Bloche. All errors, whether of omission or commission, are mine alone.

1. BrainyQuote, Will Rogers Quotes, http://www.brainyquote.com/quotes/authors/w/ will_rogers.html (last visited May 4, 2009).

2. David A. Hyman \& Mark Hall, Two Cheers for Employment-Based Health Insurance, 2 Yale J. Health Pol'y L. \& Ethics 23 (2001).

3. Id. at 23.

4. Id. at 26-43. For additional background on EBC, see David Blumenthal, EmployerSponsored Health Insurance in the United States-Origins and Implications, 355 NEW ENG. J. MED. 82 (2006); Alain C. Enthoven \& Victor R. Fuchs, Employment-Based Health Insurance; Past, Present, and Future, HeAlth AfF., Nov.-Dec. 2006, at 1538.
}

5. CNN Election Center 2008, Results: Dennis Kucinich, http://www.cnn.com/ 
two leading candidates in the Democratic primary (then-Senators Barack Obama and Hillary Clinton) both proposed to build on EBC instead of proposing to replace it. Democratic primary voters are the natural constituency for a one-payer system, but their revealed preferences (or, more likely, their expectations about the electoral appeal of that approach) obviously pointed in a rather different direction. Third, although the American Recovery and Reinvestment Act of 2009 (the "stimulus bill") expands Medicaid, unemployed workers may only participate if they qualify under existing income and wealth criteria. Instead of broadening access to Medicaid, the stimulus bill subsidizes the cost of COBRA premiums for those who wish to maintain their EBC after they have been laid off. Fourth, since taking office, President Obama has stuck to the basic position he took during the Democratic primaries: if an individual is happy with his existing coverage (which for a majority of Americans is EBC), he is free to keep it.

These realities suggest that $\mathrm{EBC}$ has more staying power than its critics might have hoped-even if the principal explanation for that staying power is nothing more compelling than inertia, or a status-quo bias if you prefer the language of behavioral economics. To be sure, the past does not necessarily predict the future in politics, policy, or finance, and health insurance falls within all three of those categories. There are also plenty of reasons to worry about how long employers will want to remain the fiscal intermediaries for their employees to obtain health coverage. But, for the moment, EBC is here to stay-and there is (as yet) no evidence we are approaching a tipping point.

Given the likely prevalence of EBC for the foreseeable future, it is worth emphasizing four important points about EBC and universal coverage. What these points have in common is that they are myths-most people believe they are true, even though they are not. ${ }^{6}$ The four "myths" are these:

1) Employers pay for $E B C$;

2) There are 45.7 million uninsured Americans;

3) Universal coverage means everyone will have access to high-quality care; and

4) Universal coverage will solve the cost problems of American health care.

ELECTION/2008/primaries/results/candidates/\#1380 (last visited May 4, 2009).

6. This is not the only article that takes this approach. See. e.g., Katherine Baicker \& Amitabh Chandra, Myths and Misconceptions About U.S. Health Insurance, HEALTH AFF., Oct. 21, 2008, at W533, http://content.healthaffairs.org/cgi/content/abstract/27/6/w533 (web exclusive); Shannon Brownlee \& Ezekiel Emanuel, Op-Ed., 5 Myth sbout Our Ailing Health Care System, Wash. Post, Nov. 23, 2008, at B3. 
Part I explains why each of these are "things people know that aren't so." Part II briefly considers whether we are likely to get to universal coverage without relying, in part, on EBC.

\section{Four Things PEOPle KNOW THAT AREN’T So}

\section{A. Employers Pav for EBC}

They don't. Although employers contribute sizeable amounts toward $\mathrm{EBC},{ }^{7}$ employees actually foot the bill in the form of foregone salary and other benefits. ${ }^{8}$ This dynamic helps explain why salaries for many workers have stagnated during the past decade: the pay increases that would otherwise have been realized as salary have been spent by employers on the rising cost of providing health insurance. ${ }^{9}$

Why should anyone care? The assumption that employers are paying for EBC means that employees and legislators are far less concerned about the cost of coverage and care (and the associated trade-offs) than would otherwise be the

7. See, e.g., Sara R. Collins, Chapin White \& Jennifer L. Kriss. The Commonwealth Fund, Whither Employer-Based Health INSURAnce? The Curri..N and Future Role of U.S. Companies in the Provision and Financing of Health Insurance (2007) ("Employer contributions to health insurance coverage comprise a substantial share of the overall financing of the U.S. health system. This year, the average employer contribution for employees enrolled in single policies is $\$ 3,785$; for family policies it is $\$ 8,824$. These contributions account for $84^{\circ} \circ$ of the full premium for single policies, and $72 \%$ of the full premium for family policies. In 2005 , total employer premium contributions for coverage of active employees and their dependents totaled about $\$ 420$ billion, over one-fifth of total U.S. health expenditure.").

8. See Anna D. Sinaiko, Employer's Response to a Pay or Play Mandate: An Analysis of California's Health Insurance Act of 2003, HeAlth AfF., Oct. 13, 2004, $\mathrm{http} / /$ content.healthaffairs.org/cgi/content/full/hlthaff.w4.469/DCl ("[E]conomic theory predicts that over the long term, employers will pass the cost of benefits to employees through lower wages

Previous studies report that in general, 83-100 percent of the costs of health insurance are shifted to employees through reduced wages."); see also Jonathan Gruber, Health Insurance and the Labor Market, 1 HandBooK of HeAlTH EConomics 645-706 (A.J. Culyer \& J.P. Newhouse eds., 2000); Linda J. Blumberg, Who Pays for Employer-Sponsored Health Insurance, HEALTH AfF., Nov.-Dec., 1999, at 58.

9. See, e.g., Brownlee \& Emanuel, supra note 6 ("Rising health-care costs are partly to blame for stagnant wages In effect, about half the money you should be earning for being more productive is being sucked up by ever more expensive health-insurance premiums."); Christine Eibner \& M. Susan Marquis, Employer's Health Insurance Cost Burden, 1996-2005, MoNTHLY LAB. REV., June 2008, at 28, 28 ("Data from the Employment Cost Index show that health insurance costs relative to payroll increased $34 \%$ between 1996 and 2005 and that the increase was largest for businesses paying low wages; simultaneously, data from the Employee Benefits Survey show that benefit packages became less generous."). 
case. Indeed, the assumption allows everyone to pretend that employers have an artesian well of money that they can use to take care of any and all medical bills incurred by their employees. The same assumption also makes it easier to criticize employers for "hollowing out" coverage and "shifting" the cost of coverage to employees.

The same (erroneous) assumption also helps explain part of the appeal of an employer mandate. ${ }^{10}$ Someone who believes that employers foot the bill for EBC will understandably regard employers who do not provide health insurance as free-riders, shirking their moral and economic obligations. In reality, in a competitive labor market, employees are paid the market rate for their services, and it is completely irrelevant (apart from the tax implications) whether compensation comes in the form of a salary only, or EBC plus a lower salary. ${ }^{11}$ Worse still, an employer mandate (as well as a pay-or-play mandate where the cost of the "pay" option is tied to the cost of coverage) effectively indexes the minimum wage to the health care inflation rate-with predictable consequences on the employment prospects for those whose marginal productivity is less than the cost of the mandated benefits.

Finally, it is possible to repackage this (factually erroneous) assumption in a way that makes employees and politicians more sympathetic to attempts by employers to control the costs of coverage - such as the claim that high health care costs hurt the global competitiveness of employers. ${ }^{12}$ Interestingly, the Obama administration has recently embraced this claim to support its efforts to remake the health care system. ${ }^{13}$ It would be more accurate to say that "high

10. See John Oberlander, The Politics of Paying for Health Reform: Zombies, Payroll Taxes. and The Holy Grail, HeALTH AFF, Oct. 21, 2008, at w544, w549 $\mathrm{http} / / /$ content.healthaffairs.org/cgi/reprint/hlthaff.27.6.w544vl (web exclusive) ("The (mis)perception that employer-sponsored insurance is paid for by employers remains a large part of employer mandate's political appeal.").

11. Of course, the existence of other benefits means that the trade-offs are more complex, since one can fund increased health coverage costs by cutting salary, cutting other benefits, or various combinations of cuts in both. Wages can also be sticky, at least in the short run. The tax implications of EBC are beyond the scope of this article. For further analysis, see Hyman \& Hall, supra note 2, at 39 .

12. Press Release, Business Roundtable, New Study Shows Health Care Costs Put U.S Workers at Significant Disadvantage Compared with Global Competitors (Mar. 12, 2009), http://www.businessroundtable.org/sites/default/files/Health\%20Value\%20Comparability $\% 20$ Stud y\%20Press\%20Release $\% 20$ FINAL $\% 20(2)$.pdf.

13. See, e.g., U.S. Dep't of Health \& Human Servs., The Costs of Inaction: The Urgent NEED FOR HEALTH REFORM 2 (2009), available at http://www.healthreform.gov/reports/inaction inactionreportprintmarch2009.pdf ("Health care costs add \$1,525 to the price of every General Motors vehicle. The company spent $\$ 4.6$ billion on health care in 2007 , more than the cost of steel. As a result of these crushing health care costs, American businesses are losing their ability to compete in the global marketplace."). 
wages" can hurt the global competitiveness of particular products produced in the United States-an observation that has nothing to do with whether the wages are spent on health care or widgets. ${ }^{14}$

\section{B. There Are 45.7 Million Uninsured Americans in the United States}

How many uninsured Americans there are depends on what you mean by "uninsured" and "American." Surveys are used to determine how many uninsured there are-but the framing of the question dramatically affects the answers one receives. Consider three different ways of asking whether someone is uninsured:

1) Were you uninsured at any point during the past year?

2) Were you uninsured for the entire past year?

3) Are you uninsured today?

Each of these questions will produce a different number of uninsured Americans-and that number can be as low as 22 million, or as high as 67 million, depending on the question and the survey population. ${ }^{15}$ The current conventional figure of 45.7 million is derived from the Census Bureau's Current Population Survey (CPS), which uses a series of questions premised on the approach of the second question above. ${ }^{16}$ Unfortunately, this approach

14. To be sure, there are other reasons for skepticism about the significance of such claims. See James F. Blumstein, On Prudence in Health Care Reform, 4 Cornell J.L. \& Pub. Pol'y 422, 426 (1995) ("If a company cannot make its prices competitive, then the company has a problem. The fact that some companies have absorbed high medical care expenses in their labor negotiations is not a good reason to nationalize the system.").

15. Catherine Hoffman \& John Holohan, Kaiser Comm'n on Medicaid \& the Uninsured, What Is the Current Population Survey Telling Us About the Number of Uninsured? 3 fig. 2 (2005) (estimating the upper bound for those uninsured ever in one year at 67 million). A more recent analysis concluded that 86.7 million Americans were without insurance at some point during 2007 and 2008. Families USA, Americans at Risk: One IN Three Uninsured 2 tbl. 2 (2009), available at http://www.familiesusa.org/assets/pdfs/americans-at-risk.pdf (showing the estimated duration of being uninsured); see also Thomas Miller, What Do We Know About the Uninsured, AMERICAN, July-Aug. 2008, http:/www.american.com/archive/ 2008/july-augustmagazine-contents/what-do-we-know-about-the-uninsured.

16. See Carmen Denavas-Walt, Bernadette D. Proctor \& Jessica C. Smith, U.S. Census Bureau, Income. Poverty, and Health Insurance Coverage n the United States: 2007, at 19 (2008), available at http://www.census.gov/prod/2008pubs/p60-235.pdf ("The Annual Social and Economic Supplement (ASEC) to the Current Population Survey (CPS) asks about health insurance coverage in the previous calendar year. The survey asks separate questions about the 
predictably leads to "a likely overcount of the number of people uninsured for the full calendar year and an undercount of the number of people who had Medicaid coverage at some point in the previous calendar year." 17 There have been various attempts to quantify the degree to which the CPS overstates how many people are uninsured for the entire year, with the precise results affected by the methodology employed. ${ }^{18}$ In the words of one set of prominent researchers in the field,

Comparisons with other surveys show that the CPS does not provide a good measure of those who are uninsured for a full year. Rather the CPS closely approximates the estimate from other surveys of the number of uninsured at a point in time. Thus, it is including both those who are uninsured throughout the full year as well as some of those who are uninsured for shorter periods of time. $^{19}$

It is not necessary to determine the optimal way of counting the uninsured to recognize that an obscure methodological decision has profoundly affected the perceived magnitude of the problem - and depending on the criteria and study one employs, figures ranging from 22 million to 67 million are defensible.

Second, commentators routinely assert that there are 45.7 million uninsured

major types of health insurance, and people who answer 'no' to each of the coverage questions are then asked to verify that they were, in fact, not covered by any type of health insurance. . People were considered 'insured' if they were covered by any type of health insurance for part or all of the previous calendar year. They were considered 'uninsured' if they were not covered by any type of health insurance at any time in that year."); HOFFMAN \& HOLOHAN, supra note 15 . at 3.

17. Hoffman \& Holohan, supra note 15 , at 2 ; see also DENAVAS-WALT ET AL., supra note 16 , at 19 ("Research shows health insurance coverage is underreported in the CPS ASEC for a variety of reasons . [B]ecause health insurance coverage status can change over the course of a year, answering questions about this long reference period may lead to response errors. For example, some people may report their insurance coverage status at the time of their interview rather than their coverage status during the previous calendar year. Compared with other national surveys, the CPS ASEC's estimate of the number of people without health insurance more closely approximates the number of people who were uninsured at a specific point in time during the year than the number of people uninsured for the entire year."). But see Jennifer Kincheloe et al., Can We Trust Population Surveys To Count Medicaid Enrollees and the Uninsured?, Health AfF., July-Aug. 2006, at 1163, 1166 ("[P]opulation surveys using carefully crafted questions to elicit self-reported measurements of health insurance can produce reasonably accurate estimates of adult Medicaid enrollment. Although most enrollees understand that they are in Medicaid and report it, some are confused about their public coverage. Evidence suggests some under- and overreporting of Medi-Cal in CHIS, perhaps because of stigma, dual enrollment, or confusion about program name, but CHIS estimates of adult Medi-Cal enrollment match administrative counts.").

18. HOFFMAN \& HolOHAN, supra note 15, at 5-7.

19. Id. at 7 . 
Americans. ${ }^{20}$ In fact, roughly 9.7 million of the 45.7 million uninsured in the CPS are non-citizens - and the rate of uninsurance is far higher among noncitizens $(43.8 \%)$ than citizens $(12.9 \%) .{ }^{21}$ These facts will be deemed completely irrelevant by some, but they are quite significant to others - including the Clinton administration. President Clinton's Health Security Act only covered citizens and legal aliens. ${ }^{22}$ The Obama administration's eight principles of health care reform do not explicitly address whether non-citizens should be covered; the plan refers at one point to "reduc[ing] the growing premiums and other costs American citizens and businesses pay for health care," and refers elsewhere to "put[ting] the United States on a clear path to cover all Americans." 23 Given the ongoing debates over immigration policy, it seems probable that many voters will be far more concerned about uninsured American citizens than uninsured noncitizens-particularly if the latter group is disproportionately composed of nonlegal aliens.

Finally, it is worth noting that the 45.7 million CPS figure also includes individuals who can afford coverage and decline it, or those who qualify for a subsidized program (e.g., SCHIP or Medicaid) but are not enrolled for one reason or another. ${ }^{24}$ To be sure, all of these individuals are still uninsured-but the list

20. See, e.g., Jennifer Pifer-Bixler, 86.7 Million Americans Uninsured over Last Two Years, CNN.com, Mar. 4, 2009, http://www.cnn.com/2009/HEALTH/03/04 uninsured.epidemic.obama; Press Release, Commonwealth Fund, Statement from Karen Davis: New Census Data on Uninsured Americans (Aug. 26, 2008), http:/www.commonwealthfund.org Content News/NewsReleases/2008/Aug/Statement-from-Karen-Davis--New-Census-Data-on-Uninsured-

Americans.aspx; Press Release, Consumers Union, Latest U.S. Census Estimates Show 45.7 Million Americans Are Uninsured (Aug. 26, 2008), http:/,ww.consumersunion.org/pub/ core_health_care/005988.html.

21.DeNavas-Walt ET AL., supra note 16, at 22 tbl.6. The Census Bureau does not break out how many of these non-citizens are non-legal aliens. A common estimate is that there are roughly 12 million "unauthorized immigrants" in the United States. CoNG. Budget OfFICE, THE IMPACT OF Unauthorized Immigrants on the Budgets of State and LoCal Governments, at Preface (2007), available at http://www.cbo.gov/ftpdocs/87xx/doc8711/12-6-Immigration.pdf.

22. Health Security Act, H.R. 3600, 103rd Cong. $\$ 1001$ (c) (1993) ("In this Act, the term 'eligible individual' means an individual who is residing in the United States and who is (1) a citizen or national of the United States; (2) an alien permanently residing in the United States under color of law . . ; or (3) a long-term nonimmigrant . . "). The President of the ACLU condemned this approach, arguing that the "Act's exclusion of aliens and incarcerated people is not only inequitable, but also irrational in terms of financial and public health considerations." Nadine Strossen, National Health Care: Will Big Brother's Doctor Be Watching L'? 4 CoRNele J.L. \& Pub. Pol'y 435, 439 (1995).

23. Obama-Care 101, The President's 8 Principles, Politico, Feb. 26, 2009, http://www.politico.com/news, stories 0209:19362,html.

24. See, e.g., Joseph Antos, Kerry, Bush and the Uninsured, AEI Health POL'Y Outlook, Sept. 3, 2004, http://www.aei.org/publications/pubID.21137/pub_detail.asp. 
of plausible strategies for addressing these specific populations is likely to differ from the list of plausible strategies for dealing with those who can't afford coverage and are not covered by an existing subsidy and/or program. For those who can afford coverage, reform might take the form of an individual mandate, access to a wider array of coverage options, or a change in the default (i.e.. autoenrollment in health insurance, thus forcing them to affirmatively opt out of coverage). For those who qualify for a subsidized program but are not currently enrolled, reform might take the form of greater outreach or more aggressive enrollment strategies.

The bottom line is that the uninsured are made up of several discrete subpopulations. Members of different sub-populations lack insurance for quite different reasons and live without insurance for varying periods of time. Treating the uninsured as a unitary entity may enhance the political salience of the problem, but it obscures the differences among sub-populations and the strategies that might be usefully employed to address the underlying problem.

\section{Universal Coverage Means Everyone Will Have Access to High-quality Care}

Health insurance is important, but having health insurance is not the same thing as having access to health care-let alone access to high-quality care. A vast body of empirical research makes both points clear and highlights the inadequacies of the care received by those who are currently insured. ${ }^{25}$ Even well-insured people have difficulty finding a primary care physician. accessing

25. See, e.g., Peter J. Cunningham \& Laurie E. Felland, Ctr. for Studyivg Health Sys. Change, Falling Behind: Americans' Access to Medical Care Deteriorates. 2003-2007. at 1 (2008) ("[I]nsured people also faced large increases in unmet need between 2003 and 2007. In fact, insured people experienced a greater percentage increase in unmet medical needs compared with uninsured people-a 62 percent increase for the insured vs. a 33 percent increase for the uninsured. As a result, ironically, the access gap between insured and uninsured people narrowed slightly

Rising out-of-pocket costs in the form of higher deductibles. coinsurance and copayments likely account for much of the increased unmet need among insured people."): JOH、E. WF $\backslash$ BERG ET AL., Dartmouth Atlas, An Agenda for Change: Improving Quality ind Curbi $\backslash$ ( Health Care SPENDING: OpPORTUNITIES FOR CONGRESS AND THE OBAMA ADMINISTR. ATION ii (2008) ("Health care in America is not nearly as good as it should be. Quality is inconsistent and often poor, rates of error are unacceptably high, and costs are higher than anywhere else in the world."): Marshall $\mathrm{H}$. Chin, Improving Care and Outcomes of Uninsured Persons with Chronic Disease Now, 149 ANNALS INTERNAL MED. 206, 206 (2008) ("Health care insurance reform is necessary for good care for chronic disease, but it will not be sufficient unless it 1s coupled with quality improvement efforts targeting the reasons that vulnerable populations with access to care often do not receive optimal care."); David A. Hyman \& Charles Silver. The Poor State of Health Care Quality in the U.S. Is Malpractice Liability. Part of the Problem or Part of the Solution?. 95 CORNELl L. Rev. 893 (2005) (reviewing evidence on the quality of care that is provided); Barbara Starfield \& Leiyu Shu, The Medical Home, Access to Care, and Insurance: A Review of Evidence. 113 Pediatrics 1493 (2004). 
the health care system during evenings and weekends, and obtaining health care when they travel.

Those more inclined to rely on anecdotal evidence should consider the case of Deamonte Driver, a twelve-year-old African American child who lived in Maryland. ${ }^{26}$ Deamonte and his brother DaShawn were covered by Medicaid, which provides comprehensive insurance coverage, including dental care. Neither received regular dental care-and when DaShawn got a toothache, his mother had great difficulty finding a dentist willing to see him-let alone an oral surgeon able to extract several teeth that had become abscessed. ${ }^{27}$ When Deamonte complained of a headache, his mother took him to the hospital, which gave him "medicine for a headache, sinusitis and a dental abscess." ${ }^{28}$ It is unclear whether his mother attempted to find a dentist to treat Deamonte's dental abscess-but her experiences with DaShawn made clear the difficulties and delays she would have faced. In short order, the infection spread from the abscess to Deamonte's brain, and it resulted in two operations, six weeks of hospitalization, and, ultimately, death.

Why couldn't Deamonte and DaShawn find a dentist, even though both had insurance? Maryland's Medicaid program paid so little that only $16 \%$ of Maryland dentists were willing to accept Medicaid patients, and only $31 \%$ of the children in the Maryland Medicaid program received any dental services in $2005 .^{29}$ These problems are not unique to Maryland: in 2005, only $29.3 \%$ of children on Medicaid in the District of Columbia and $24.3 \%$ of children on Medicaid in Virginia saw a dentist. ${ }^{30}$ These problems are also not unique to dentistry: access problems for Medicaid beneficiaries are pervasive because of

26. Mary Otto, For Want of a Dentist, WASH. POST, Feb. 28, 2007, at Bl; see also The Story of Deamonte Driver and Ensuring Oral Health for Children Enrolled in Medicaid: Hearing Before the Domestic Policy Subcomm. of the H. Comm. on Oversight and Government Reform, 110th Cong. (2007) (statement of Lorrie J. Norris, Public Justice Center), available at http://domesticpolicy.oversight.house.gov/documents/20070516164514.pdf [hereinafter Norris Testimony].

27. After Ms. Driver was unable to find a dentist on her own, she contacted the Public Justice Center (PJC) in Baltimore, Maryland. The PJC contacted twenty-six dentists that the Medicaid benefits administrator thought were participating in the program. None of them were willing to see a Medicaid patient. The PJC then contacted the Medicaid enrollee helpline run by the Maryland Department of Health and Mental Hygiene (DHMH). "Over the next 5 days, the DHMH case management nurse, a case manager at the Prince George's County Health Department's ombudsman unit, and an employee at United Healthcare/Americhoice worked together" to try to find a dentist for Deamonte's brother and make an appointment. Norris Testimony, supra note 26, at 5 .

28. Otto, supra note 26.

29. Id.

30. Id. 
low and slow payments and administrative headaches. ${ }^{31}$ Medicare beneficiaries and those with private insurance are experiencing access problems as well, and those problems are getting worse over time. ${ }^{32}$

To summarize, universal coverage does not mean that everyone will receive care-let alone high-quality care. Addressing those problems will require attention to the delivery-side of the market.

\section{Universal Coverage Will Solve the Cost Problems of American Health Care}

It won't. But don't take it from me. Just ask President Obama:

If we don't address cost, I don't care how heartfelt our efforts are, we will not get this done. If people think we can simply take everybody who is not insured and load them up in a system where costs are out of control, it's not going to

31. See, e.g., Peter J. Cunningham \& Jessica May, Ctr. for Studying Health Sys. Change, Medicaid Patients increasingly Concentrated Among Physicials 3 (2006), available at http://www.hschange.com/CONTENT/866/866.pdf ("Relatively low Medicaid payment rates and high administrative burdens are major reasons for not accepting Medicaid patients, according to physicians .. These concerns also likely explain why physicians in smaller practices are increasingly closing their practices to new Medicaid patients."); Peter J. Cunningham \& Ann S. O'Malley, Do Reimbursement Delays Discourage Medicaid Participation by Physicians?, HEAlth AfF., Nov. 18, 2008, at w17, http://content.healthaffairs.org/cgi content/full/28/1/w17? (web exclusive) ("Surveys show that about half of physicians accept all new Medicaid patients into their practices, compared with more than 70 percent for privately insured or Medicare patients. .. . Low Medicaid reimbursement rates relative to those of Medicare and private payers are usually considered to be the primary reason for low physician participation in Medicaid. Medicaid fee levels vary considerably across states, and research has consistently shown that Medicaid participation by physicians is higher in states with higher fees than in states with lower fees."); Kevin Sack, In Massachusetts, Universal Coverage Strains Care, N.Y. Times, Apr. 5, 2008, at Al (quoting Dr. Katherine Atkinson, a family physician in Amherst, Massachusetts: "I calculated that every time I have a Medicaid patient, it's like handing them a \$20 bill when they leave.").

32. See Cunningham \& Feland, supra note 25; Marc Siegal, When Doctors Opt Out, Wall St. J. Apr. 17, 2009, at A13 ("[T]he Medicare Payment Advisory Commission reported in 2008 that $28 \%$ of Medicare beneficiaries looking for a primary care physician had trouble finding one, up from $24 \%$ the year before. The reasons are clear: A 2008 survey by the Texas Medical Association, for example, found that only $38 \%$ of primary-care doctors in Texas took new Medicare patients. The statistics are similar in New York state, where I practice medicine. More and more of my fellow doctors are turning away Medicare patients because of the diminished reimbursements and the growing delay in payments. I've had several new Medicare patients come to my office in the last few months with multiple diseases and long lists of medications simply because their longtime provider--who they liked-abruptly stopped taking Medicare. ... The problem is even worse with Medicaid. ... HMOs are problematic as well."). 
happen. We will run out of money. ${ }^{33}$

Whether universal coverage will make it easier to solve the cost problems of American health care is, of course, a different question-but the early returns from Massachusetts are not particularly encouraging. ${ }^{34}$ Several commentators have asserted that the Massachusetts approach (do universal coverage first, and then do cost control) will make it easier to implement cost control, ${ }^{35}$ but there is

33. CNN.com, Transcripts, http://transcripts.cnn.com/TRANSCRIPTS/0903/05/ sitroom.01.html (transcript of The Situation Room, aired on Mar. 5, 2009).

34. See, e.g., Diane Archer, Inst. for Am.'s Future, Massachusetts health Reform: Near Universal Coverage, But No Cost Controls or Guarantee of Quality, Affordable HEALTH CARE FOR ALL (2009), available at http://ourfuture.org/healthcare/massachusetts ("While reform has been very effective at increasing accessibility of insurance . . the Massachusetts model is unsustainable, with skyrocketing costs and no systems in place to drive value."); David A. Hyman, The Massachusetts Health Plan: The Good, the Bad, and the Ugly, 55 U. KAN. L. REV. 1103,1115 (2007) ("Finally, the regulations that were adopted do nothing about the cost of health care in Massachusetts - and in the long run, that problem will swamp any reform proposal, including the Massachusetts health plan."); Kevin Sack, Hith Health Care for Nearly All, Massachusetts Now Faces Costs, N.Y. TIMES, Mar. 15, 2009, at A1 ("Those who led the 2006 [Massachusetts reform] effort said it would not have been feasible to enact universal coverage if the legislation had required heavy cost controls. The very stakeholders who were coaxed into the tent - doctors, hospitals, insurers and consumer groups-would probably have been driven into opposition by efforts to reduce their revenues and constrain their medical practices, they said. Now those stakeholders and the state government have a huge investment to protect.").

35. See, e.g., Jonathan Gruber, The Treatment, Response: In Massachusetts, We Got Reform Right, NEW REPUBLIC, Mar. 22, 2009, http://blogs.tnr.com/tnr/blogs/the_treatment/archive 2009 / $03 / 22 /$ response-in-massachusetts-we-got-reform-right.aspx ("[T]he Massachusetts law explicitly did not take on the fundamental determinants of medical cost growth-and this is, in my mind, the genius of the approach. For decades, efforts to move towards universal coverage have always floundered on the shoals of cost control [T] he choice between coverage first or coverage as part of a comprehensive cost control package is a false one. Coverage first is the natural stepping stone to a comprehensive cost control. By bringing everyone into the tent of insurance coverage, and getting all the interest groups behind a common goal, a move to universal coverage could be viewed in retrospect as the key step towards the cost control this country so desperately needs."); see also Michael Vitez, Mass. Health Care Has Lessons, PHIL. InQuirer, Mar. 31, 2009, at Al ("'We did it right in Massachusetts. That's the most important lesson,' said Stuart Altman, a healthpolicy expert at Brandeis University. 'The first part was cover everyone, make it work . . Trying to control costs brings every constituent group out against you."'); Jonathan Cohn, The Treatment, Massachusetts Miracle-or Catastrophe?, NEw RePUBLIC, Mar. 17, 2009. http://blogs.tnr.com/tnr/blogs/the_treatment/archive/2009/03/17/massachusetts-miracle-or-

disaster.aspx ("Note, by the way, that the state is now moving forward on cost control. A new commission is investigating ways of moving the state away from straight fee-for-service and towards payment systems that reward high quality and efficiency . . [M]any officials and experts in Massachusetts have argued that it is the clear progress on coverage that makes this new discussion possible."). 
no evidence to support that assertion, beyond generalized expressions of optimism, and the hope that forthcoming recommendations from yet another blue-ribbon commission will be game-changing. ${ }^{36}$ Even those who believe that this approach is sound recognize that cost-containment is likely to be an extremely tough sell in Massachusetts. ${ }^{37}$

Putting the dynamic in poker terms, Massachusetts has gone "all in" on coverage - based on the hope that providers will fold on cost-containment. If they don't, President Johnson anticipated the likely impact on the Massachusetts state budget and the health care system:

Well, I remember one time they were giving a test to a fellow who was going to be a switchman on the railroad, giving him an intelligence test, and they said, "What would you do if a train was coming east going sixty miles per hour, and you looked over your shoulder and another one was coming from the west going sixty miles an hour?". . And the fellow said, "I'd go get my brother." And they said, "Why would you get your brother?" And he said, "Because he hasn't ever seen a train wreck." 38

36. See, e.g., Sack, supra note 34 ("Both Gov. Deval Patrick and a high-level state commission have set out to revamp the way public and private insurers reimburse physicians and hospitals. They want a new payment method that rewards prevention and the effective control of chronic disease, instead of the current system, which pays according to the quantity of care provided. By late spring, the commission is expected to recommend such a system to the legislature."); Gruber, supra note 35 ("[D]oing coverage first is the single most important thing we can do to get to cost control . . . We have one of the strongest and most effective adrocacy groups for health care for the poor in the country . . After playing such an important role in passing our law, this group suddenly realized that their hard won gains may be lost if we didn 't eventually figure out a way to control health care costs. The result was an intense and broad-reaching campaign that resulted in the most significant cost-control legislation we have seen in Massachusetts in at least fifteen years. This includes the appointment of a commission. This legislation, and commission, would simply not have happened without our reform law motivating concerted action to preserve the gains we have made for the uninsured. Whether this commission can make headway in a state so dominated by the health care sector is uncertain, but at least more progress is being made than had been made in recent years.").

To be clear, I certainly agree that we should change the ways in which we compensate health care providers. See, e.g., David A. Hyman \& Charles Silver. You Get What You Pay for: Result-Based Compensation for Health Care, 58 WASH. \& LEL L. REV. 1427 (2001).

37. See, e.g., Sack, supra note 34 ("[T] he task of cost-cutting remains difficult in a state with a long tradition of heavy spending on health care. Massachusetts has more doctors per capita than any state, Boston is home to some of the country's most expensive academic medical centers. and a new state law requires comprehensive benefits like prescription drug and mental health coverage. 'Just as this may have been the easiest place to do coverage, it may be the most difficult place to do cost control,' said Jonathan Gruber, a health economist at the Massachusetts Institute of Technology.").

38. David Blumenthal \& James Morone, The Lessons of Success-Revisiting the Medicare 
Finally, it is interesting to speculate how our nation's budgetary policies, procurement and programmatic decisions, and tax burdens might differ from the status quo if legislators and the executive branch routinely followed a similar "dessert first, spinach later, we hope" approach.

\section{UNIVERSAL COVERAGE AND EBC}

It is clear that EBC won't deliver universal coverage. In 2007, EBC covered about 177.4 million people, or roughly $60 \%$ of the population. ${ }^{39}$ The percentage of the population that is covered by EBC depends on the interaction of a host of factors, including the cost of coverage, the size and sophistication of the employer, the market sector in which the employer competes, whether the employer is unionized, and the availability of publicly-financed coverage. The terms on which EBC is offered (including whether it is offered at all), and whether there is uptake, are also contingent on larger macroeconomic trends and a host of decisions and trade-offs made by individual employers and employees. Because EBC is "employment based coverage," job loss and loss of insurance generally go together. ${ }^{40}$ To be sure, newly unemployed workers have the right to purchase COBRA coverage from their former employers-but many are unable to afford the substantial associated premiums once they are unemployed-and it remains to be seen whether the subsidy for such premiums in the stimulus bill will close the gap. More generally, Medicare, Medicaid, and SCHIP were enacted because EBC proved incapable of ensuring universal coverage. ${ }^{41}$ Yet, it

Story, 359 New EnG. J. MED. 2384, 2385 (2008) (quoting President Johnson).

39. DeNavas-WaLt ET AL., supra note 16, at 61 tbl.C-1.

40. See Robert Pear, When A Job Disappears, So Does the Health Care, N.Y. TIMES, Dec. 6, 2008 , at A30. The standard estimate is that every $1 \%$ increase in the unemployment rate results in an additional 1 million uninsured individuals. See KAISER COMM $v$ ON MEDICAID AND THE Uninsured, Rising Unemployment, Medicaid and the Uninsured, A Multi-Year Snapshot of StATE FinAnCING EFFECTS (2009) ("Assuming that states maintain eligibility levels for public programs, every one percentage point increase in unemployment is likely to result in one million more Medicaid and SCHIP enrollees and 1.1 million more uninsured.).

In an interview on PBS, Uwe Reinhardt, in typically understated fashion, suggested that "the devil systematically built our health insurance system [with] the feature that when you're down on your luck, you're unemployed, you lose your insurance [O]nly the devil could ever have invented such a system. Humans of goodwill would never do this." PBS.org, Healthcare Crisis: Uwe E. Reinhardt, Ph.D., http:/www.pbs.org/healthcarecrisis/Exprts_intrvw/ u_reinhardt.htm (last visited May 4, 2009). As I have noted elsewhere, Reinhardt does not consider the possibility that the Devil has a diversified portfolio. See generally David A. Hyman, MEdiCARE MEETS MEPHISTOPHELES xviii (2006).

41. Of course, this is a separate question than the degree of crowd-out caused by these programs. See generally David M. Cutler \& Jonathan Gruber, Does Public Insurance Crowd Out Private Insurance'. 111 Q.J. ECoN. 391 (1996); Jonathan Gruber \& Kosali Simon, Crowd-Out Ten Years Later: Have Recent Public Insurance Expansions Crowded Out Private Health Insurance?, 
does not follow that the United States can get to universal coverage without EBC, for two distinct reasons: budgetary reality and the logic of collective action.

Budgetary reality creates a substantial incentive for policymakers to build on existing institutional arrangements, rather than start over from scratch. The budgetary issue is simple: strategies to replace EBC outright will require the government to impose substantial additional taxes. Enthusiastic supporters of universal coverage will view those taxes as a reasonable exchange for the resulting health insurance security-but that opinion is far from universal. ${ }^{42}$ Public support for health reform predictably drops dramatically once a price-tag is attached - and the larger the price-tag, the larger the drop.

Stated differently, taxes matter. The basic design of President Clinton's Health Security Act (specifically, the reliance on regional alliances to collect premiums and arrange for coverage) was driven by the Administration's need to keep the Congressional Budget Office ( $\mathrm{CBO}$ ) from scoring the premiums as taxes. ${ }^{43}$ When the CBO scored those payments as taxes, the Act was effectively dead. ${ }^{44}$ During the campaign before the 2008 election, one of President Obama's

(Nat'l Bureau of Econ. Research Working Paper No. 12858, 2007), available at http://www.nber.org/papers/w12858.

42. See Oberlander, supra note 10, at w547 ("When middle-class, insured Americans think about health reform, what they have in mind is not a proposal to make their health insurance benefits subject to taxation.")

43. See William M. Sage, Legislating Delivery Sistem Reform: A 30,000 Feet View of the 800 Pound Gorilla, HeAlth AfF., Nov.-Dec. 2007, at 1553, 1554 ("Two principal elements of that plan (nominally private 'health alliances' and global limits on premiums) existed mainly to persuade the Congressional Budget Office to confer a favorable 'score."').

44. See Ezra Klein, The Number Cruncher in Chief, Am. Prospect, Jan. 14. 2009, http://www.prospect.org/cs/articles?article=numbercruncherinchief ("How much a bill costs is central to whether it gets enacted. And not just how much it costs but how much the CBO says it costs. The Number. The CBO's most famous—or infamous-intervention in a legislative battle was its estimate of the 1994 Clinton health-care proposal. 'The major issue,' recalls Robert Reischauer, then director of the CBO, 'was not how much it cost but whether the premiums that you were charged as an individual were governmental in nature and would thus be in the budget.' Reischauer and the CBO decided they were. The premiums paid by every American would be included in the Number. This meant the Number was huge - vastly larger than the price tag previously affixed to the proposal by the Clinton administration. Hearing the news, one senior administration official moaned to the Washington Post, 'The Republicans will jump all over this and say we're increasing the budget by 25 percent and putting through the biggest tax increase in history.' The New York Times editorialized that 'the opponents of President Clinton's health care bill think they have struck political gold in an analysis of the bill just released by the Congressional Budget Office.' They were right. Donna Shalala, Clinton's secretary of health and human services, called the ruling 'devastating.' That was the Number, and it helped kill the bill.").

The significance of the CBO decision is also shown by the pressure CBO came under from President Clinton's supporters to treat the alliances as private entities. See HAYNES JOHNSON \& David S. Broder. The SYSTEM 283-284 (1996) ("The politics became intense, personal, and 
most popular ads emphasized that he would follow a different course: "On health care reform -- two extremes. On one end, government-run health care, higher taxes. On the other, insurance companies without rules, denying coverage. Barack Obama says both extremes are wrong., ${ }^{, 45}$

The practical politics of the situation are related to the budgetary realities, but they also reflect the underlying collective action problem. Machiavelli nicely summarized the challenge awaiting potential reformers:

And it should be realised that taking the initiative in introducing a new form of government is very difficult and dangerous, and unlikely to succeed. The reason is that all those who profit from the old order will be opposed to the innovator, whereas all those who might benefit from the new order are, at best tepid supporters of him. This lukewarmness arises partly from fear of their side, partly from the skeptical temper of men, who do not really believe in new things unless they have been seen to work well. ${ }^{46}$

As I noted in the pages of this journal eight years ago, "in health care, there are .. too few people who are fundamentally dissatisfied with the coverage they now have, for comprehensive reform to be politically viable." ${ }^{47}$ Although dissatisfaction with the American health care system is certainly widespread, it has not yet reached the critical mass necessary to eliminate EBC. ${ }^{4}$

abusive. As time for his final report neared, Reischauer was subjected to the most intense and unpleasant pressure of his life .... 'I received numerous phone calls,' Reischauer said some weeks later, 'from people of great fame and with common household names telling me what they thought the right answer to this question was and questioning why I would have the audacity to decide otherwise.' Some who called accused him of trying to destroy a President. Others angrily warned him that if health reform died because of an unfavorable CBO verdict, children would suffer, and some would die. That's going to be on your conscience, he was told.")

Senator Kennedy was particularly abusive. See id. at 284-285 ("For nearly half an hour, Kennedy assailed Reischauer, bellowing his outrage: Reischauer was going to bring down the Clinton administration. Here was a President with a once-in-a-lifetime opportunity to do something as historic as health reform, and you, a minor staff official, are taking it upon yourself to thwart the will of the American people. The American people elected President Clinton because they wanted to have national health insurance, and now when the President is delivering on that promise, you block him. You aren't elected. Who are you to say the President didn't fulfill his promise? Who are you to say this isn't private insurance? Who are you to say whether this is on budget or off budget?")

45. BarackObama.com, BarackTV. Ads, http://origin.barackobama.com/tv/advertisements (use scrollbar on the right to select "Two Extremes" ad).

46. Niccolo Machiavelli, The Prince 20-21 (Quentin Skinner \& Russell Prince eds., Cambridge Univ. Press 1988) (1513).

47. See Hyman \& Hall, supra note 2, at 39.

48. See Robert J. Blendon et al., Voters and Health Reform in the 2008 Presidential Election. 359 NEW ENG. J. MED. 2050, 2051 (2008) ("The majority of respondents rate the state of the U.S. 
Again, don't take my word for it; if the issue had reached a tipping point, the administration's reform proposal would not have as its starting point "if you like your current health insurance, nothing changes." 49 Of course, "nothing changes" only if EBC remains available on terms that employers and employees find acceptable and affordable, and the proposed "public plan" option does not exploit its monopsony power - and none of those things are guaranteed. ${ }^{50}$ Indeed, proponents will candidly admit that the whole point of the public plan is to exploit the government's monopsony purchasing power, in order to encourage employers and employees to abandon private insurance entirely. ${ }^{51}$

health care system at the time of the election as 'fair' or 'poor,' and although most respondents do not see the health system as being in a crisis situation today, they do see it as facing major problems.")

49. White House, The Agenda - Health Care, http://www.whitehouse.gov/agenda/health_care (last visited Apr. 6, 2009).

50. See, e.g., Richard A. Epstein, The Taxation of Employee Health Care Benefits, ForBEs. Mar. 17, 2009, http://www forbes.com/2009/03/16/taxation-employee-benefits-opinionscolumnists-healthcare.html ("Earmarking these new dollars for helping the uninsured will salvage the centerpiece of the Obama health care policy, which builds existing employer health care plans as a key driver for broader health care coverage. What he fails to see is that present employer health care coverage is not immutable $\quad[\mathrm{H}]$ igh marginal tax rates will surely overshoot the mark by putting an enormous crimp in job creation and retention. The present health care system could easily unravel as unemployment rises, and employer health plans fall by the wayside. Total nationalization is the likely long-run outcome."); Laura Meckler, Health Care Battle Set To Focus on Public Plan, Wall ST. J., Mar. 24, 2009, at A4 ("Opponents say a public plan would be an unfair competitor because it could become big enough to drive down reimbursements to doctors and hospitals, much like Medicare does, putting more cost pressure on the private sector. Consumers would then flock to the public plan because its premiums would be cheaper, opponents fear, and ultimately no viable private plans would remain."); Karen Tumulty, Max Baucus and the "Public Plan," Swampland, Mar. 26, 2009, http://swampland.blogs.time.com/2009/03 26/maxbaucus-and-the-public-plan ("The insurance companies hate this idea, saying it . . would be unfair for them to be forced to compete with the government. Many health care experts, however, argue that this provision is crucial, as a means of holding down health care costs. (The idea being that the government would use its muscle--much as it does in the Medicare and Veterans Administration programs--to negotiate lower reimbursement rates.) Conservatives oppose it as well, because they see it as a first step toward a (anadian-style single-payer system.").

51. See, e.g., Ezra Klein, A Public Insuranc' Option Primer, Aw. Prospect, Mar. 26, 2009, http://www.prospect.org/csnc/blogs/ezraklein_archive?month=03\&year=2009\&base_name=a_publ ic_insurance_option_prim ("A public insurance plan able to use Medicare's bargaining power to secure deep discounts for its customers and ensure the maximum possible network would be cheaper and more efficient than private insurers. Over time, this increased efficiency would make the plan more attractive because it could offer more coverage for less money. As consumers recognized this fact, they would increasingly migrate towards the plan, and the public insurer would become, if not a de facto single payer system, something close to it. The public insurer, in this scenario, is a game changer. But it's a game-changer because it's a form of single payer using a 
In combination, these factors lead to the basic dynamic outlined above: EBC won't get you to universal coverage, but it is hard to see how you get to universal coverage without EBC, given the status quo. Finally, insured Americans are more likely to support a health reform proposal when it does not (at least initially) disrupt their existing coverage arrangements.

\section{CONCLUSION}

EBC is not perfect-but perfection is not the appropriate standard for judging real world policies and institutions. To believe otherwise is to indulge in the nirvana fallacy. ${ }^{52} \mathrm{~A}$ better approach is to recognize that "bad is often best, because it is better than the existing alternatives." ${ }^{53}$ When assessing the merits of the EBC-based status quo and of any given reform, it is critical to understand the advantages and disadvantages of both. ${ }^{54}$

Critics of EBC routinely treat the existence of the uninsured as a moral trump card, justifying condemnation of employers and the imposition of an employer mandate. Such arguments are fundamentally mistaken. As I have noted previously,

Employers provide coverage (or fail to do so) out of self-interest, and employees accept or decline coverage after making a similar assessment. Employers operate in a competitive labor market - and they are no more morally blameworthy for failing to offer insurance to their employees than they are blameworthy for not paying their minimum wage employees more than

mild version of monopsony buying power."); Timothy Noah, Lemon Capitalism: What a Level Playing Field for Health Insurance Really Means, SLATE, Mar. 27, 2009, http://www.slate.com/id/2214801; see also Meckler, supra note 50; Tumulty, supra note 50.

52. See Richard Epstein, Simple Rules fOr a COMPlex World 32 (1995) ("First-best solutions are rarely if ever, possible; thus the beginning of wisdom is to seek rules that minimize the level of imperfections, not to pretend that these do not exist. No contract, no association is ever bullet proof: no matter what rights, duties, institutions, and remedies are chosen, in some circumstances they will be found wanting. Bad outcomes are therefore consistent with good institutions and we cannot discredit these institutions with carefully selected illustrations of their failures. Counterexamples may be brought to bear against any set of human institutions. The social question, however, is concerned with the extent of the fall from grace. The fact of the fall should be taken as a necessary truth, not a shocking revelation. Perfection is obtainable in the world of mathematics, not in the world of human institutions."); Harold Demsetz, Information and Efficienc1" Another Viewpoint, 12 J.L. \& ECON. 1, 1 (1969) ("The view that now pervades much public policy economics implicitly presents the relevant choice as between an ideal norm and an existing 'imperfect' institutional arrangement. This nirvana approach differs considerably from a comparative institution approach in which the relevant choice is between alternative real institutional arrangements.").

53. See Neil Komesar, Imperfect Alternatives 204 (1997).

54. See Hyman \& Hall, supra note 2, at 26-38 (cataloging the costs and benefits of EBC). 
minimum wage. Similarly, employees who decline to accept coverage either assess their risks differently, or simply have a better use for their money than buying coverage. There is no compelling theoretical or practical reason to treat all of these decisions, which occur in the shadow of a competitive labor market, as a failure of employers or of the employment-based coverage market.

The availability of employment-based pooling mechanisms may (or may not) offer the best opportunity to address various social problems, but this possibility should not be viewed as creating a moral obligation on the part of employers to meet the social needs that our society has proven unwilling to address, despite repeated opportunities to do so. ${ }^{55}$

To be sure, defaults do matter-and a well-structured "nudge" has the potential to get some of those who are currently uninsured into the systemparticularly if the price they are charged reflects the value of the coverage they receive, and not a covert attempt to cross-subsidize those with a different risk/cost profile. ${ }^{56}$ Regardless, universal coverage will cost real money, and "[a]ll of the major financing options have serious political liabilities; they risk arousing either public opposition and anti-tax sentiment or stakeholder opposition, or both." 57

To summarize: talk is cheap; health care is expensive. The underlying problems in the coverage market are attributable to both market failure and government failure - and even if we get to universal coverage, equally (if not more) daunting challenges await us on the delivery-side of the market.

55. Id., at 41-42; see also David A. Hyman. Health Insurance: Market Failure or Government Failure, 14 CONN. INS. L.J. 307 (20)(8).

56. See, e.g., Richard Thalir \& Cass Sunstein, Nudge: Improing Decisions About HEALTH, WEALTh, AND HaPpiness (2008).

57. Oberlander, supra note 10. 